\title{
STATIC ANALYSIS AND SIMPLIFIED DESIGN OF SUSPENSION BRIDGES HAVING VARIOUS RIGIDITY OF CABLES
}

\author{
Tatjana Grigorjeva ${ }^{1}$, Algirdas Juozapaitis ${ }^{2}$, Zenonas Kamaitis ${ }^{3}$ \\ Vilnius Gediminas Technical University, Saulètekio al. 11, LT-10223 Vilnius, Lithuania \\ E-mails: ${ }^{1}$ tatjana.grigorjeva@vgtu.lt; ${ }^{2} a l g i r d a s . j u o z a p a i t i s @ v g t u . l t ;{ }^{3}$ zenonas.kamaitis@vgtu.lt
}

Received 20 Jan. 2010; accepted 20 May 2010

\begin{abstract}
Increased deformability can be considered as the basic disadvantage of suspension bridges. One of the ways to increase the rigidity of a suspension bridge is to transfer a part of stiffening girder rigidity to a suspension main cable. To give the suspension bridge more stable appearance, the authors propose to use the cables of varying bending stiffness. The main cables can be made of standard section shapes or have a composite section. The object of this work was to study a method for analyzing and determining the internal forces in the main cables and stiffening girder under static loading to provide recommendations for designing suspension bridges with stiffened cables. Simple formulas are presented for determining displacements, internal forces and stresses in the main cable and stiffening girder. Finite element modeling was performed. The final part of the paper discusses design procedures for such suspension systems. An example of a pedestrian suspension bridge is appended.
\end{abstract}

Keywords: suspension bridges, rigid cables, displacements, internal forces, FE modeling, design procedures, example of footbridge.

\section{Introduction}

Suspension bridges are the most important and attractive structures possessing a number of technical, economical and aesthetic advantages. Increased deformability can be considered as the basic disadvantage of suspension bridges. Because suspension bridges are relatively light and flexible, they are all susceptible to traffic loads and wind. Some suspension bridges suffered from structural failure in the past. The most famous example is the Tacoma Narrows Bridge built in 1940 and collapsed after 4 months during a windstorm (Irvin et al. 2005). Similar failures to Takoma of some British and American bridges are reported in reference (Barelli et al. 2006).

It should be also mentioned that the cables of suspension bridges are vulnerable to corrosion which is difficult to detect. Inspections of the main cables in suspension bridges have revealed a significant evolution of corrosion process and broken wires just after 30-40 years in service (e.g. Betti et al. 2005; Cremona 2003; Mayrbaurl 2000; Nakamura et al. 2000). In some bridges, due to corrosion, the main cables had to be replaced (e.g., Colford and Clark 2009).

A suspension bridge is inherently a flexible structure and in the majority of cases special measures of stiffening must be incorporated in the design. On highway or walkway bridges, the rigidity is achieved by stiffening the bridge deck using diagonal or zigzag suspenders or combined hybrid systems (combination of suspension and cable-stayed system). Steel trusses and girders are often used to keep the road deck stiff. Damping systems are also sometimes used to minimize deck vibrations due to traffic or wind actions (e.g., Anusas et al. 2007).

The stabilization of the deformability of a suspension system could be done by giving certain bending stiffness to the suspension cables (Juozapaitis, Norkus 2007; Юозапайтис et al. 2002; Качурин et al. 1971; Москалев 1980). An example is the suspension bridge in Pittsburgh (Качурин et al. 1971). The stiffening girder in this bridge is practically absent and all loads are transferred to the main cable. The famous Tower Bridge in London also demonstrates the idea of stiffening the main cables (Troyano 2003). Two outside spans are carried on two pairs of stout chains united by powerful ties. To give the suspension bridge more stable appearance, the authors also proposed to use the cables of varying bending stiffness (Grigorjeva et al. 2004).

In general, the deformability of suspension systems depends on the kinematical character of displacements of a flexible suspension cable. Today, flexible cables are made of the multiple strands of wire. In the analysis of suspension bridges, the main cables are generally assumed to have no flexural stiffness and to be subject to axial tension only. The analysis and design of suspension bridges with flexible cables are based on the deflection theory, which requires the solution of complex differential equations (Podolny and Goodyear 2006 and others). Similar approach can be used for suspension bridges with stiffened cables. Although any of the well-known theories are complex and involves several procedures and approximations, a new concept of solving displacement equation in the analysis of suspension systems with stiffened cables is given by the authors in reference (Grigorjeva et al. 2004). The primary objective of the proposed 
method is to give a simplified and adaptable design procedure to provide design aids for suspension system evaluation and practical recommendations. It is evident that a comparison has to be envisaged by the results obtained by the proposed simplified method and by other, more detailed procedures. The finite element method is a powerful instrument for this purpose.

This paper presents the results of theoretical analysis and finite element modeling of the influence of the stiffness of the main cables on the static behaviour of suspension bridges as well as recommendations for designing such bridges.

\section{Description of structure}

A suspension bridge with the main cables of various bending stiffness is a type of a bridge in which the main cable is composed of factory-prefabricated erection segments joined together and resisting axial forces and bending moments. The main cables conditionally are called as "rigid" or "stiffened" cables. The types of bridges vary in the configuration of cross-sections, the shape of the cable axis, the number of cable hinges with regard to technical, economic or aesthetic reasons.

The cross-section of cables may be I-shaped, boxshaped or tubular made of standard steel profiles, including rolled shapes (Fig. 1a) or have composite sections (Fig. 1b). They may be also designed as trusses (Fig. 1c). Several types of composite members can be used. For example, concrete-filled steel or FRPC tubular or rectangular solid or hollow cross-sections can be an attractive solution (Kuranovas and Kvedaras 2007; Soundararajan and Shanmugasundaram 2008). The layout of the cable axis and its sag, e.g., the height-to-span ratio varies within wide limits. The cables are suspended between towers and may be two or three-hinged with a third hinge at a middle-span.

This solution allows translating a part of stiffening beam rigidity to the main cable. The role of the stiffened cable is to constrain the deformations and displacements of the whole suspension system. In general, the main cables must be designed for combined stresses due to axial tension and bending.

There are two construction scenarios of cable erection stages to be considered. The construction of the bridge begins with the main cable which is of small segments and erected by the use of a cable crane running on suspender cables. During the construction process, prefabricated segments are lifted in the design position and can be joined together to form the main stiff cable when they are just into place (scenarios A) or after the erection of a bridge deck (scenarios $\mathrm{B}$ ). In the first case, construction loads, i.e. the weight of the deck is supported by the stiffened cable. In the second case, the suspension segments are hinged and carry the whole permanent load during construction as an absolutely flexible cable, but live load is applied on the whole suspension system with the stiffened main cables. It is evident that the erection stages must be taken into account in the design process. More information on this subject can be found in our previous publication (Grigorjeva et al. 2010). a)

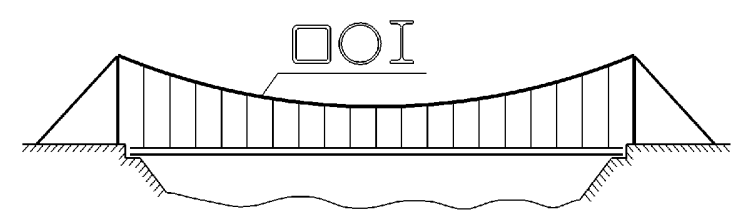

b)

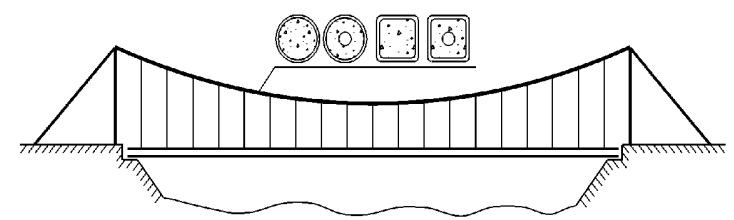

c)

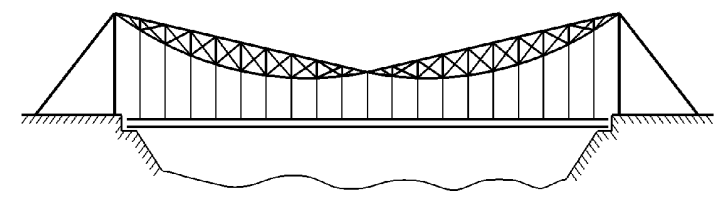

Fig. 1. Basic types of innovative suspension bridges with stiffened main cables

Finally, the following can be mentioned among the expected advantages provided by the cables of various stiffness:

- possibility of variation in stiffness and the initial shape of the main cables allowing to control stresses, deflections or displacements in the members of the suspension system;

- reduction of systems deformability that is capable of resisting substantial symmetrical, unsymmetrical or local superimposed loads without special stabilization measures;

- significant savings in detailing nods, connections and anchorages;

- reduction of the cost for inspection, monitoring and protection of cables against corrosion.

\section{Basis of design}

The analysis and design of suspension bridges with flexible cables by the deflection theory assuming constant bending stiffness $E I$, uniformly distributed live load $q$ and including the vertical deflection $\eta$ of the cable (and stiffening girder) at any point $x$ involves the solution of the well-known differential equation (e.g., Podolny and Goodyear 2006):

$$
E I \eta^{I V}(x)-H \eta^{\prime \prime}(x)=\left(H-H_{g}\right) y^{\prime \prime}(x)+q,
$$

where $H$ and $H_{g}$ is the cable thrust produced by uniform total and dead load, respectively.

The solution of the differential equation is expressed in terms of hyperbolic or exponential functions. In all cases, the existing method of analysis is tedious and involves several procedures and approximations.

The method presented here considerably simplifies the calculations involved without significant sacrifice of accuracy. The basic principles of the simplified analytical method for suspension bridges with the finite flexural 
rigidity of cables by considering two scenarios of bridge construction is proposed by the authors and is presented in our previous publications (Grigorjeva et al. 2006, 2010). The method is based on the following assumptions:

- deflections of the stiffening girder and rigid cable are strictly elastic;

- stiffening beam is loaded only by live load and is stressless under the dead load;

- stiffening beam of the constant moment of inertia is simply supported at the ends;

- suspenders are subject to tension only; their elongation under loading is neglected;

- suspenders are uniformly stressed along the whole length of span for any given imposed loading;

- loads are uniformly distributed to the main cable through discrete suspenders.

The model was developed from a simple equation of compatibility condition of deformations by considering the initial length of cable axis $S_{0}$ and cable axis elongation $\Delta S_{H}$ due to cable thrust force $H$ :

$$
S=S_{0}+\Delta S_{H},
$$

where $S$ is the length of cable axis after elongation.

By substituting the values of $S, S_{0}$, and $\Delta S_{H}$ in Eq. (2), the following equation is obtained:

$$
L+\frac{8\left(f_{0}+\Delta f_{0}\right)^{2}}{3 L}=L+\frac{8 f_{0}^{2}}{3 L}+\frac{H \cdot L}{E A_{c a b}},
$$

where $f_{0}$ is the initial cable sag; $\Delta f_{0}$ is the vertical deflection of the cable at mid-span; $L$ is span length.

The cable thrust $H$ is given by the expression:

$$
H=\frac{p_{c a b} L^{2}}{8\left(f_{0}+\Delta f_{0}\right)}-\frac{48 \Delta f_{0} E I_{c a b}}{5 L^{2}\left(f_{0}+\Delta f_{0}\right)} .
$$

The load taken by the cable:

$$
p_{c a b}=p-\frac{80 E I_{\text {gird }} \Delta f_{0}}{L^{4}},
$$

where $p=g+q=p_{\text {cab }}+p_{\text {gird }}$ is total load.

Substituting in Eq. (3) the values for $H$ and $p_{c a b}$ from Eq. (4) and (5) and assuming that $\Delta f_{0}^{2} \approx 0$, the equation for the increment of the initial sag or vertical deflection at the mid-span of the bridge will be:

$$
\Delta f_{0}=\frac{0.375 p L^{4}}{16 f_{0}^{2} k_{1}+28.8 f_{0} k_{2}+30 k_{3}},
$$

where $k_{1}=E A_{c a b}$ is tension stiffness of the cable; $k_{2}=E I_{c a b}$ is bending stiffness of the cable; $k_{3}=E I_{\text {gird }}$ is bending stiffness of the stiffening girder.

Later, the influence of changes in environmental temperature and horizontal movements of tower saddles, the systems with three hinged or inclined cables and with different cable layouts were examined by the authors for this application.
Let us consider a simple model of one span suspension bridge and a stiffening girder supported by a parabolic rigid cable symmetrically or unsymmetrically loaded and situated on one half of deck length distributed loads with temperature change $\Delta t$ and horizontal movements of tower saddles $\delta_{h}$ as shown in Fig. 2. We will consider construction scenarios $\mathrm{A}$, when rigid cables are completely erected before the suspenders and stiffening girder are attached to them.

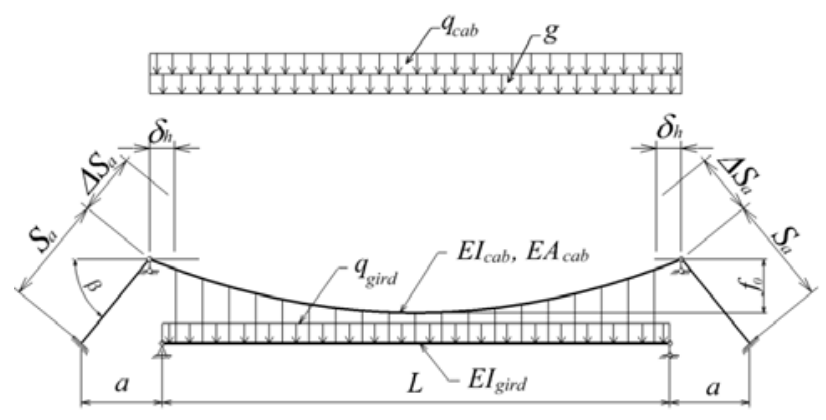

Fig. 2. Basic structural system

To develop general formulas for these cases of actions becomes rather cumbersome and, for this reason, the derivation of such formulas has been omitted here. The general equations for vertical deflections and superimposed loads in the main cable and stiffening girder are presented in Table 1. These formulas have been developed using tbe general principle presented above. It can be observed that the structure is analyzed, at first, for symmetrical loading $p=g+q$ situated along the whole deck length [Eqs. (1)-(4)]. Unsymmetrical loading can be thought of as the sum of two full-span loadings: symmetrical loading $p_{1}=g+q / 2$ (loading I) and unsymmetrical loading of $q / 2$ (loading II). For dead load $g$ the rigid cable is designed to create axial and bending stresses. Bending the cable and stiffening girder is caused by live load $q$.

The first task of analysis is to determine the vertical deflections of the given suspension system under all actions involved in the analysis. Having thus obtained vertical deflection, the next step required is computing the load parts that are taken by the main cable through the suspenders and that by the stiffening beam. Note, that this redistribution of loads is influenced by an appropriate method of bridge erection. After the loads taken by the main members of the bridge are obtained, bending moments, shearing forces and stresses can be easily computed using well-known expressions.

The proposed analytical method results in considerably simpler mathematical computations and was used in all instances to compare the results obtained with the numerical simulation.

\section{Comparison of analytical method with FEsimulation}

In order to check the analytical method and to determine vertical deflections, the internal forces and stresses of suspension bridge members under the distributed static loading, FEM was used. Analysis was performed with 
a relatively simple FE model using commercial finite element software CosmosM and Midas/Civil. The elements TRUSS3D were used to represent the flexible cable (Model 1), suspenders and backstays. Beam elements
BEAM3D were used for rigid cables (Model 2), stiffening the girder and towers. The girder deck and cables are hinged to the tower footings and tower saddles, respectively.

Table 1. General equations and loading conditions

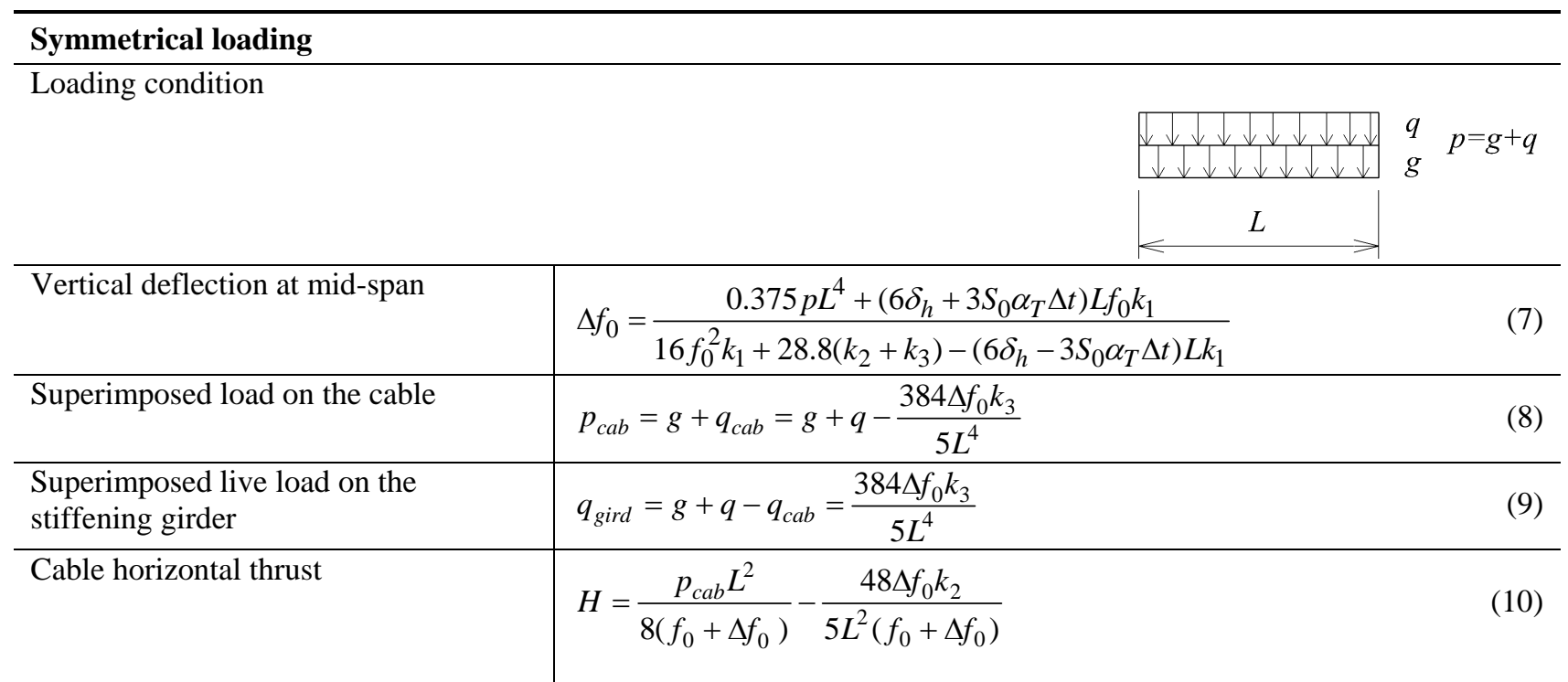

\section{Unsymmetrical loading}

Loading condition (I)

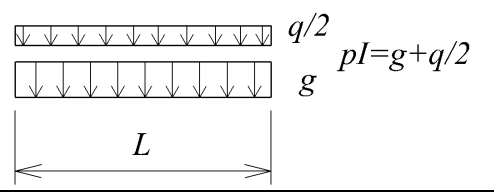

A new value of $\Delta f_{01}$ is found by substituting $p_{I}=g+q / 2$ for $p=g+q$ in Eq. (7). By introducing the new value of $\Delta f_{01}$ into Eqs. (8)-(10), we obtain the values of $p_{c a b I}$ [Eq. (8a)], $q_{\text {girdI }}$ [Eq. (9a)], and $H_{I}$ [Eq. (10a)].

Loading condition (II)

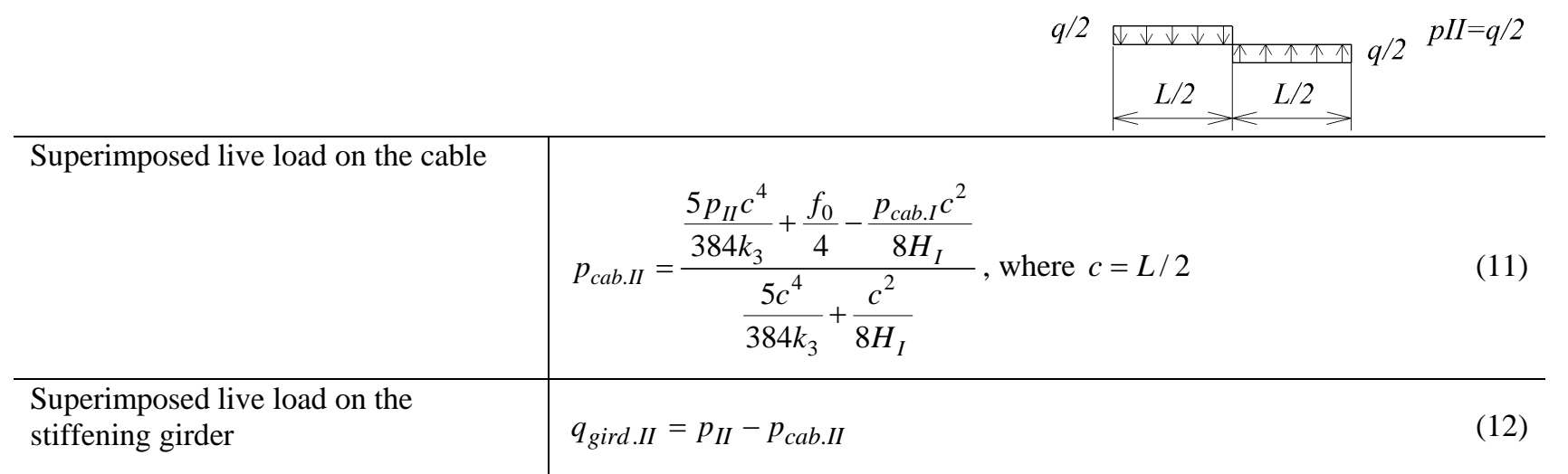

Loading condition (I + II)

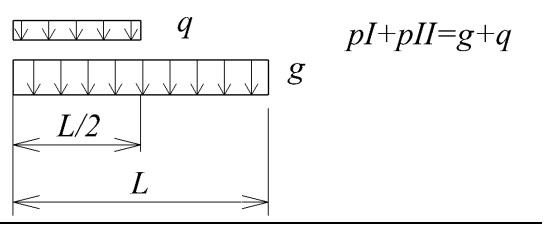

\begin{tabular}{l|l}
\hline $\begin{array}{l}\text { Vertical deflection at the left and right } \\
\text { quarterpoint of the span }\end{array}$ & $\Delta f_{0.25 . l / r}=\frac{\left(p_{\text {cab.I }} \pm p_{\text {cab.II }}\right) c^{2}}{8 H_{I}}-\frac{f_{0}}{4}$ \\
\hline
\end{tabular}


Table 2. Comparison of computed and predicted values of the main parameters

\begin{tabular}{|c|c|c|c|c|c|c|}
\hline \multirow[b]{2}{*}{ Parameters } & \multicolumn{3}{|c|}{ Construction scenarios A } & \multicolumn{3}{|c|}{ Construction scenarios B } \\
\hline & $\begin{array}{c}\text { Computed by } \\
\text { analytical } \\
\text { method }\end{array}$ & $\begin{array}{c}\text { Predicted by } \\
\text { FE } \\
\text { simulation }\end{array}$ & $\begin{array}{l}\text { Ratio of computed } \\
\text { to predicted }\end{array}$ & $\begin{array}{l}\text { Computed by } \\
\text { analytical } \\
\text { method }\end{array}$ & $\begin{array}{c}\text { Predicted by } \\
\text { FE } \\
\text { simulation }\end{array}$ & $\begin{array}{c}\text { Ratio of } \\
\text { computed } \\
\text { to predicted }\end{array}$ \\
\hline \multicolumn{7}{|c|}{ Symmetrical loading } \\
\hline$\Delta f_{0}, \mathrm{~m}$ & 0.040 & 0.038 & 1.05 & 0.022 & 0.020 & 1.10 \\
\hline$H, \mathrm{kN}$ & 1544 & 1539 & 1.0 & 915 & 899 & 1.02 \\
\hline$M_{c a b, \max }, \mathrm{kNm}$ & 10.6 & 10.1 & 1.05 & 5.3 & 5.0 & 1.06 \\
\hline$M_{\text {gird,max }}, \mathrm{kNm}$ & 17.6 & 14.9 & 1.18 & 8.7 & 33.2 & 1.17 \\
\hline$\sigma_{c a b, \max }, \mathrm{MPa}$ & 50.0 & 48.1 & 1.04 & 38.9 & 7.6 & 1.14 \\
\hline$\sigma_{\text {gird,max }}, \mathrm{MPa}$ & 2.9 & 2.4 & 1.20 & 1.4 & 1.2 & 1.17 \\
\hline \multicolumn{7}{|c|}{ Unsymmetrical loading } \\
\hline$\Delta f_{0,25 l}, \mathrm{~m}$ & 0.339 & 0.305 & 1.11 & 0.316 & 0.280 & 1.13 \\
\hline$\Delta f_{0,25 r}, \mathrm{~m}$ & -0.321 & -0.284 & 1.13 & 0.310 & 0.279 & 1.11 \\
\hline$H, \mathrm{kN}$ & 1166 & 1130 & 1.03 & 1170 & 1090 & 1.07 \\
\hline$M_{c a b, \max , l}, \mathrm{kNm}$ & 356.6 & 320.1 & 1.11 & 332.5 & 302.5 & 1.10 \\
\hline$M_{c a b, \max , r}, \mathrm{kNm}$ & -337.1 & -298.1 & 1.13 & 326.1 & 295.2 & 1.10 \\
\hline$M_{\text {gird,max }, l}, \mathrm{kNm}$ & 594.9 & 525.6 & 1,13 & 587.6 & 525.5 & 1.12 \\
\hline$M_{\text {gird,max,r }}, \mathrm{kNm}$ & -588.9 & -515.4 & 1.14 & 585.4 & 521.3 & 1.12 \\
\hline$\sigma_{c a b, \max , l}, \mathrm{MPa}$ & 122.2 & 117.1 & 1.04 & 116.1 & 107.9 & 1.08 \\
\hline$\sigma_{c a b, \max , r}, \mathrm{MPa}$ & 117.2 & 112.3 & 1.04 & 114.5 & 99.8 & 1.14 \\
\hline$\sigma_{\text {gird,max,l }}, \mathrm{MPa}$ & 98.5 & 93.2 & 1.05 & 97.2 & 90.9 & 1.07 \\
\hline$\sigma_{\text {gird,max }, r}, \mathrm{MPa}$ & 97.4 & 91.4 & 1.06 & 96.9 & 88.9 & 1.09 \\
\hline
\end{tabular}

The following data were used in the numerical simulation (see Fig. 2): $L=100 \mathrm{~m}, a=15 \mathrm{~m}, f_{0}=10 \mathrm{~m}$, width of the deck $2.5 \mathrm{~m}$, spacing of suspenders $5 \mathrm{~m}$, $\beta=45^{\circ}$. The main rigid cable, stiffening girder and back stays are steel profiles of a rectangular cross-section. The rigidity of the cable is $E I_{c a b}=273627 \mathrm{kNm}^{2}$ and $E A_{c a b}=7245000 \mathrm{kN}$ and that of stiffening girder $E I_{\text {gird }}=453912 \mathrm{kNm}^{2}$.

The predicted displacements, moments and stresses of $3 \mathrm{D}$ model were compared to the results of the proposed analytical method using the values of cable to girder bending stiffness ratio $\xi=E I_{c a b} / E I_{\text {gird }}=0-1.0$ and live to dead load ratio $\gamma=p / q=1-3$. As an example, Table 2 shows a comparison of computed and predicted maximum vertical displacements, bending moments and stresses for symmetrical and unsymmetrical loading using the values $\xi=E I_{c a b} / E I_{\text {gird }}=0.6$ and $\gamma=p / q=1.0$. The computed results using bridge construction scenarios $B$ are also presented from our previous publication (Grigorjeva et al. 2010). As expected, the proposed analytical approach gives a satisfactory but slightly conservative prediction, as indicated by the values of the ratio computed/predicted of more than unity. The highest value of this ratio is 1.20 and the average is 1.096 with standard deviation of 0.049 . Detailed analysis showed that ratio $\xi$ and $\gamma$ have no influence on this ratio.

Since a good agreement is obtained between computed results by the proposed method and predicted responses by FE simulation, the analytical method of behavior analysis is to be adequate for a preliminary static analysis and design of suspension bridges.

\section{Design flow}

The design procedures of the proposed design method presented above are summarized in the flow chart given in Fig. 3.

The input data, given or assumed, necessary to implement the design procedure are the bridge span and layout (shape and sag) of the cable, the method of bridge erection and superimposed loads. The cross sections of the rigid cable and stiffening girder are selected and the dead load is computed. The rigid cable shape and initial sag can be determined according to recommendations given in the author's reference (Grigorjeva et al. 2004).

Summarizing the whole procedure, we observe that the solution of the suspension bridge resolves itself into four successive principle steps:

- determine vertical deflections of stiffening girder under the action of symmetrical and unsymmetrical loads; 
- determine the parts of the load that are taken by the main cable and stiffening girder;

- determine internal forces resulting from static loads, horizontal thrust and temperature changes;

- determine stresses in critical cross sections.

Once the internal forces or stresses are determined, limit states must be checked, if one limit state is not satisfied, the design is revised accordingly.

The presented design procedure should be considered as simplified. The selected members may now be checked by more detailed methods to see if their behavior satisfies serviceability and strength criteria. This step is beyond the scope of the present paper.

\section{Design example}

The following numerical example demonstrates the applicability of the proposed design method. For a design example, consider the suspension footbridge shown in
Fig. 4. The footbridge (over the main street in Vilnius, Lithuania) was designed with a total length of $99 \mathrm{~m}$ and $4 \mathrm{~m}$ wide deck. The structural scheme is a suspension bridge with a central span of $L=65 \mathrm{~m}$ having two towers and a composite steel-concrete deck. The bridge was designed for a live load of $q=5 \mathrm{kN} / \mathrm{m}^{2}$.

Other data are as follows: $\beta=65017^{\circ} ; a=25 \mathrm{~m}$; $f_{0}=6.5 \mathrm{~m}$; the initial length of cable axis $S_{0}=L+\frac{8 f_{0}^{2}}{3 L}=66.7 \mathrm{~m} ; \alpha_{T}=12 \cdot 10^{-6} 1 /{ }^{\circ} \mathrm{C} ; \Delta t=25.1^{\circ}$ (RSN 156-94); $\delta_{h . u}=0.05 \mathrm{~m}$.

Rigid cable HEM $280-I_{\text {cab }}=39550 \cdot 10^{-8} \mathrm{~m}^{4}$; $A_{c a b}=240.2 \cdot 10^{-4} \mathrm{~m}^{2} ; \quad W_{c a b}=2551 \cdot 10^{-6} \mathrm{~m}^{3} ; k_{1}=E A_{c a b}=$ $504.4 \cdot 10^{4} \mathrm{kN} ; k_{2}=E I_{c a b}=8.306 \cdot 10^{4} \mathrm{kNm}^{2} ; E=2.1 \cdot 10^{8} \mathrm{kN} / \mathrm{m}^{2}$; steel S275, $f_{y, d}=f_{y} / \gamma_{M}=275 / 1.1=250 \mathrm{MPa}$. Stiffening girder IPE $550-I_{\text {gird }}=67120 \cdot 10^{-8} \mathrm{~m}^{4} ; W_{\text {gird }}=2441$. $10^{-6} \mathrm{~m}^{3} ; k_{3}=E I_{\text {gird }}=14.095 \cdot 10^{4} \mathrm{kNm}^{2}$; steel S235, $f_{y, d}=f_{y} / \gamma_{M}=235 / 1.1=213.6 \mathrm{MPa}$.

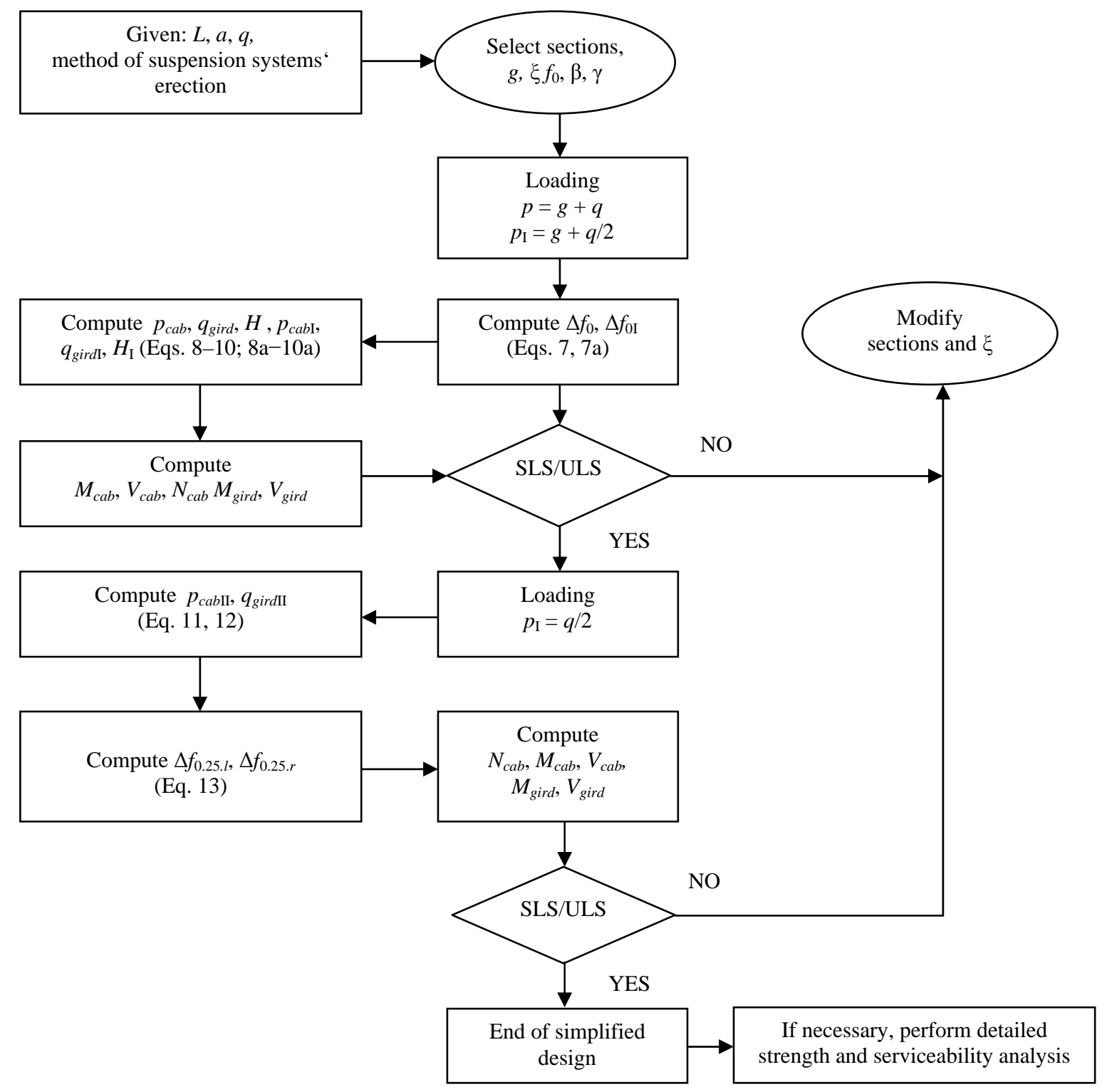

Fig. 3. Simplified flow chart for the proposed design procedure of analytical method 


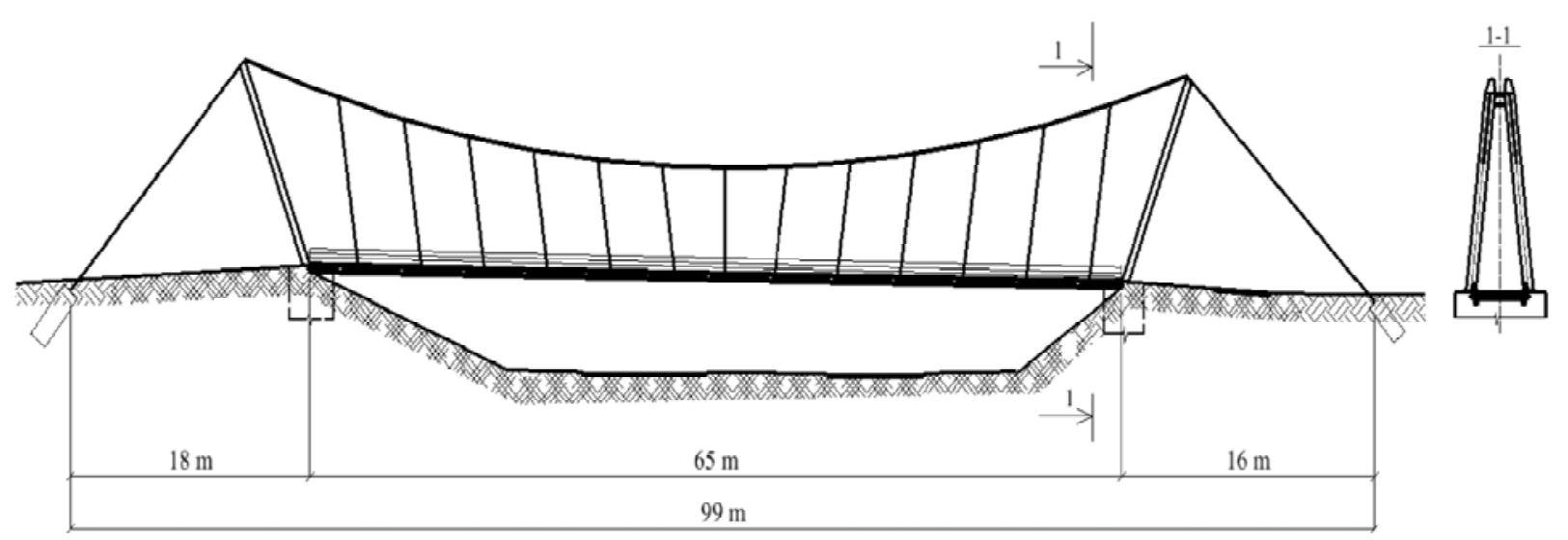

Fig. 4. General layout of a suspension footbridge

$\xi=E I_{\text {cab }} / E I_{\text {gird }}=0.59$; superimposed characteristic dead load $g_{k}=10.5 \mathrm{kN} / \mathrm{m}$ (design load $g=13.6 \mathrm{kN} / \mathrm{m}$ ); characteristic live load $q_{k}=10 \mathrm{kN} / \mathrm{m}(q=13 \mathrm{kN} / \mathrm{m}) ; \gamma=$ $q / g=0.95$.

Static analysis was undertaken using the flow chart shown in Fig. 3 and FM-modeling with CosmosM. The design of the bridge has been carried out using the criteria from STR 2.05.08:2005.

\section{Solution}

For the solution, logical steps outlined in the design procedure (Fig. 3) together with the equations derived in the paper are followed throughout the example.

Step 1 - Substituting relevant values in Eqs. (7) and (7a) respectively, we obtain:

$\Delta f_{0}=0.30 \mathrm{~m}$ and $\Delta f_{0 I}=0.274 \mathrm{~m}$.

Step 2 - From Eqs. (8), (9), (8a), and (9a), respectively:

$p_{c a b}=26.4 \mathrm{kN} / \mathrm{m}$;

$q_{\text {gird }}=0.2 \mathrm{kN} / \mathrm{m}$;

$p_{\text {cab.I }}=19.93 \mathrm{kN} / \mathrm{m}$;

$q_{\text {gird } . I}=0.17 \mathrm{kN} / \mathrm{m}$.

Step 3 - From Eqs. (10) and (10a), respectively:

$H=2000 \mathrm{kN}$;

$H_{I}=1547 \mathrm{kN}$.

Step 4 - The internal forces (if necessary and stresses) in the cable and stiffening girder under uniformly distributed symmetrical load are determined by the well-known formulas:

$M_{c a b}=\frac{48 \Delta f_{0} k_{2}}{5 L^{2}}$, to be $M_{c a b}=54.1 \mathrm{kNm}$;

$V_{c a b}=\frac{p_{c a b} \cdot L}{2}$, to be $V_{c a b}=858 \mathrm{kN}$;

$N_{c a b}=\sqrt{H^{2}+V_{c a b}^{2}}$, to be $N_{c a b}=2176.3 \mathrm{kN}$;
$M_{\text {gird }}=\frac{q_{\text {gird }} L^{2}}{8}$, to be $M_{\text {gird }}=105.6 \mathrm{kNm}$;

$V_{\text {gird }}=\frac{q_{\text {gird }} L}{2}$, to be $V_{\text {gird }}=6.5 \mathrm{kN}$.

Step 5 - Limit state analysis is to be done applying STR 2.05.08:2005 method to verify compliance with design criteria. Due to the limited space of the paper, this verification is omitted here.

Step 6 - From Eqs. (11) and (12), respectively:

$p_{\text {cab.II }}=3.51 \mathrm{kN} / \mathrm{m}$;

$q_{\text {gird } . I I}=p_{I I}-p_{\text {cab.II }}=2.99 \mathrm{kN} / \mathrm{m}$.

Step 7 - From Eq. (13):

$\Delta f_{0,25 . l}=0.376 \mathrm{~m}$;

$\Delta f_{0,25, r}=-0.223 \mathrm{~m}$.

Step 8 - The internal forces (stresses) in the cable and stiffening girder under the action of uniformly distributed symmetrical dead load and unsymmetrical live load:

$M_{c a b . l / r}= \pm \frac{48 \Delta f_{0.25 l / r} k_{2}}{5 c^{2}}$, to be $M_{c a b . l}=284.2 \mathrm{kNm}$ and $M_{\text {cab.r }}=-168.3 \mathrm{kNm}$;

$V_{c a b . \max }=\frac{\left(p_{c a b . I}+p_{c a b . I I}\right) L}{2}$, to be $V_{c a b . \max }=716.8 \mathrm{kN}$;

$N_{c a b . \max }=\sqrt{H_{I}^{2}+V_{c a b . \max }^{2}}$, to be $N_{c a b . \max }=1705 \mathrm{kN}$;

$M_{\text {gird } . l / r}=\frac{\left(q_{\text {gird.I }} \pm q_{\text {gird.II }}\right) c^{2}}{8}$, to be

$M_{\text {gird } . l}=416.6 \mathrm{kNm}$ and $M_{\text {gird } . r}=-372.8 \mathrm{kNm}$;

$V_{\text {gird.max }}=\frac{\left(q_{\text {gird.I }}+q_{\text {gird.II }}\right) c}{2}$, to be $V_{\text {gird.max }}=$

$51.35 \mathrm{kN}$.

Step 9 - Structural elements have to be checked with respect to limit states.

The rigid cable is subject to axial tension and bending, maximum stress according to STR 2.05.08:2005 prescriptions should satisfy 


$$
\begin{aligned}
& \frac{N_{E d}}{A_{\text {net }}} \pm \frac{M_{y, E d}}{I_{y, n e t}} z \pm \frac{M_{z, E d}}{I_{z, \text { net }}} y= \\
& \frac{1705.0}{240.2 \cdot 10^{-4}}+\frac{284.2}{39550 \cdot 10^{-8}} \cdot 0.14+\frac{0}{0}= \\
& 171.6 \mathrm{MPa}<f_{y, d} \gamma_{c}=250 \cdot 0.9=225 \mathrm{MPa} .
\end{aligned}
$$

Maximum moment capacity for stiffening girder is

$$
\frac{M_{E d}}{M_{C, R d}}=\frac{416.6}{469.3}=0.89<1.0 \text {. }
$$

\section{Conclusions}

The application of finite flexural rigidity cables for suspension bridges using standard steel profiles, welded sections or lightweight trusses is an attractive solution to increase the stiffness of suspension systems. A simplified analytical method is proposed (Table 1) to analyze and preliminary design suspension bridges with the varying rigidity of cables under the action of symmetrical and unsymmetrical uniformly distributed static loads. The influence of ambient temperature variation, horizontal displacement of main cable supports and the method of bridge erection can be also taken into consideration. The analytical method is based on the compatibility condition of deformations and a suitable redistribution of loads on the rigid cable and stiffening girder. The method has been developed as a simple but applicable method for preliminary design. By this analysis, suspension bridges may be designed for proper behavior and strength without using a more complicated deflection theory based on differential equations and hyperbolic or exponential functions.

The proposed analytical method was compared with FE analysis data. The analytical method tended to overestimate displacements and internal forces, although, yielded generally comparable results (within about 3-20 percent) with regard to the predicted FE simulation.

To check the design accuracy of the proposed simplified analytical method and to demonstrate some of its capabilities, an example of a pedestrian suspension bridge is presented. Simple steps are given for implementing the proposed procedure (Fig. 3). It has been shown that compared with common types of steel suspension bridges, the systems with rigid cables provide certain advantages such as considerable reduction in system deformability, simpler detailing and corrosion protection, savings of materials.

\section{References}

Anusas, S.; Notkus, A.; Kamaitis, Z. 2007. Stabilisation of vibration of footbridges, in The 9th International Conference "Modern Building Materials, Structures and Techniques”, May 16-18, 2007, Vilnius, Lithuania, 2: 734-739.

Barelli, M.; White, J.; Billington, D. P. 2006. History and aesthetics of the Bronx-Whitestone Bridge, Journal of Bridge Engineering 11(2): 230-240. doi:10.1061/(ASCE)1084-0702(2006)11:2(230)

Betti, R.; West, A. C.; Vermaas, G.; Cao, Y. 2005. Corrosion and embrittlement in high-strength wires of suspension bridge cables, Journal in Bridge Engineering 10(2): 151-162. doi:10.1061/(ASCE)1084-0702(2005)10:2(151)

Colford, B. R.; Clark, C. A. 2009. Feasibility study into the replacement or augmentation of the main cables of a longspan suspension bridge, Bridge Structures: Assessment, Design and Construction 5(2-3): 119-133. doi:10.1080/15732480903142500

Cremona, C. 2003. Probabilistic approach for cable residual strength assessment, Engineering Structures 25(3): 377-384. doi:10.1016/S0141-0296(02)00173-6

Grigorjeva, T.; Juozapaitis, A.; Kamaitis, Z. 2004. Structural analysis of suspension bridges with varying rigidity of main cables, in Proceedings of the 8th International Conference "Modern Building Materials, Structures and Techniques”, Vilnius, Lithuania, May 19-22, 2004, 469472.

Grigorjeva, T.; Juozapaitis, A.; Kamaitis, Z. 2006. Simplified engineering design method of suspension bridges with rigid cables under action symmetrical and asymmetrical loads, The Baltic Journal of Road and Bridge Engineering 1(1): 11-20.

Grigorjeva, T.; Juozapaitis, A.; Kamaitis, Z. 2010. Influence of construction method on the behaviour of suspension bridges with main rigid cables, in Proceedings of the 10th International Conference "Modern Building Materials, Structures and Techniques”, May 19-21, Vilnius, Lithuania, 2: 628-634.

Irvin, P. A.; Stoyanoff, S.; Xie, J.; Hunter, M. 2005. Tacoma Narrows 50 years latter - wind engineering investigations for parallel bridges, Bridge Structures 1(1): 3-17. doi:10.1080/1573248042000274551

Juozapaitis, A.; Norkus, A. 2007. Determination of rational parameters for the advanced structure of a pedestrian suspension steel bridge, The Baltic Journal of Road and Bridge Engineering 2(4): 173-181.

Kuranovas, A.; Kvedaras, A. K. 2007. Behaviour of concretefilled steel tubular composite elements, Journal of Civil Engineering and Management 13(2): 131-141.

Mayrbaurl, R. M. 2000. Corrosion in suspension bridge cables, in Proc of the $16^{\text {th }}$ Congress of IABSE "Structural Engineering for Meeting Urban Transportation Challenges", September 18-21, 2000, Lucerne, 8 [CD-ROM].

Nakamura, S.; Kitagawa, M.; Furuya, K.; Suzumura, K. 2000. Corrosion performance of new suspension bridge cable protection, in Proc of the $16^{\text {th }}$ Congress of IABSE "Structural Engineering for Meeting Urban Transportation Challenges”, September 18-21, 2000, Lucerne, 8 [CDROM].

Podolny, W.; Goodyear, D. 2006. Chapter “Cable suspended bridges”, in Structural Steel Designer's Handbook. McGrow-Hill, USA: 15.1- 16.91.

Soundararajan, A.; Shanmugasundaram, K. 2008. Flexural behaviour of concrete-filled steel hollow sections beams, Journal of Civil Engineering and Management 14(2): 107-114. doi:10.3846/1392-3730.2008.14.5

Troyano, L. F. 2003. Bridge Engineering. A Global Perspective. London: Tomas Telford Ltd. 775 p.

Качурин, В; Брагин, А.; Ерунов, Б. 1971. Проектирование висячих и вантовых мостов [Katchurin, V.; Bragin, A.; Erunov, B. Design of Suspension and Cable-Stayed Bridges]. Москва: Транспорт. 280 с.

Москалев, Н. 1980. Конструкции висячих покрытий [Moskaliov, N. Construction of suspension coverings]. Москва: Стройиздат. 336 с. 
Юозапайтис, А.; Шарашкин, В.; Григорьева, Т.; Валюнас, Б. 2002. Расчет и компоновка висячих конструкций из прямолинейных элементов [Juozapaitis, A.; Sharashkin, V.; Grigorjeva, T.; Valiūnas, B. Analysis and arran- gement of suspension structures from straight-line elements of finite flexural stiffness], Theoretical Foundations of Civil Engineering - X. OW PW Warsaw, 887-896.

\section{STATIŠKAI APKRAUTŲ KABAMUৃJŲ TILTŲ SU KINTAMOJO STANDŽIO LYNAIS ANALIZE் IR SUPAPRASTINTAS PROJEKTAVIMAS}

\section{T. Grigorjeva, A. Juozapaitis, Z. Kamaitis}

\section{S a n trauka}

Esminis kabamujų tiltų trūkumas - didelis jų deformatyvumas. Deformatyvumui sumažinti autoriai siūlo dalị standumo sijos lenkiamojo standžio perduoti kabamajam lynui. Baigtinio lenkiamojo standumo lynai gali būti daromi iš standartinių valcuotujų profiliuočių arba sudètinio skerspjūvio. Šio darbo tikslas - pateikti supaprastintą metodiką kabamojo tilto standaus lyno ir standumo sijos elgsenos analizei atlikti bei rekomendacijas tokiems statiškai apkrautiems tiltams projektuoti. Pateiktos paprastos formulès lyno ir sijos poslinkiams, įrąžoms ir įtempiams apskaičiuoti. Atliktas kabamosios tilto sistemos modeliavimas baigtiniais elementais. Aptartos tokių kabamujų tiltų projektavimo procedūros. Pateiktas pėsčiujų viaduko kabamujų konstrukcijų projektavimo pavyzdys.

Reikšminiai žodžiai: kabamieji tiltai, standūs lynai, poslinkiai, įrąžos, BE modeliavimas, projektavimas, pėsčiuju viadukas.

Tatjana GRIGORJEVA. PhD, Assoc. Prof. at the Dept of Architectural Engineering. Author and co-author of 15 scientific publications. Research interests: long - span bridges, dynamics of bridges.

Algirdas JUOZAPAITIS. PhD Assoc. Prof. at the Dept of Bridges and Special Structures. Author and co-author of more than 40 scientific publications. Research interests: development and nonlinear analysis of bridges and special structures.

Zenonas KAMAITIS. Dr Habil, Prof. Emeritus at the Dept of Bridges and Special Structures. Member of IABSE since 1999. Author and co-author of more than 170 publications, including 6 books. Research interests: special structures and bridges, materials, durability, monitoring and refurbishment. 